\title{
Riedel Thyroiditis: A Rare Case of Chronic Thyroiditis
}

\author{
A Chaouki*, K Chaker, N Zouhair, K Choukry, R Abada, S Rouadi, M Roubal and M Mahtar \\ Department of ENT, University Hospital Centre IBN ROCHD, Casablanca, Moracco
}

Submission: January 25, 2019; Published: February 06, 2019

*Corresponding author: A Chaouki, Department of ENT, University Hospital Centre IBN ROCHD, Casablanca, Moracco

\begin{abstract}
Riedel's thyroiditis (RT) is a rare form of chronic thyroiditis characterized by extensive fibrosis of the thyroid gland, also affecting adjacent tissue, clinically resembles anaplastic thyroid or lymphoma. Findings from ultrasonography, and cytology are rarely conclusive. the therapeutic approach remains empirical and imperfect. We report a rare case of RT in a Moroccan woman with a good evolution after combined, surgical and medical therapy.

Keywords: Riedel's; Fibrosing Thyroiditis; Thyroiditis
\end{abstract}

\section{Introduction}

Riedel thyroiditis (RT) is a rare fibrosing disorder, with etiology that is largely unknown, characterized by extension of the fibro inflammatory process beyond the thyroid capsule [1]. Because of its rarity, only few cases have been recorded in medical literatures. The estimated incidence is 1.06 per 100,000 populations accounting for $0.06 \%$ and $0.05 \%$ of thyroidectomies. More than 100 years ago, Riedel described 3 cases of a peculiarly hard, infiltrative lesion of the thyroid gland, this unusual thyroid disorder became known as Riedel's thyroiditis [2]. The diagnosis can be evoked clinically but only the anatomo-pathological examination confirms this disorder and discards the other differential diagnosis. The treatment of this benign condition is based on corticosteroid therapy which often helps to stabilize the disease. The place of surgery remains limited to providing material for anatomopathological study and especially to the decompression of the VADS; it exposes to the recurential and vascular complication [3]. We report a case of a women with
Riedel thyroiditis cured with combined thyroidectomy and corticosteroids.

Case Report

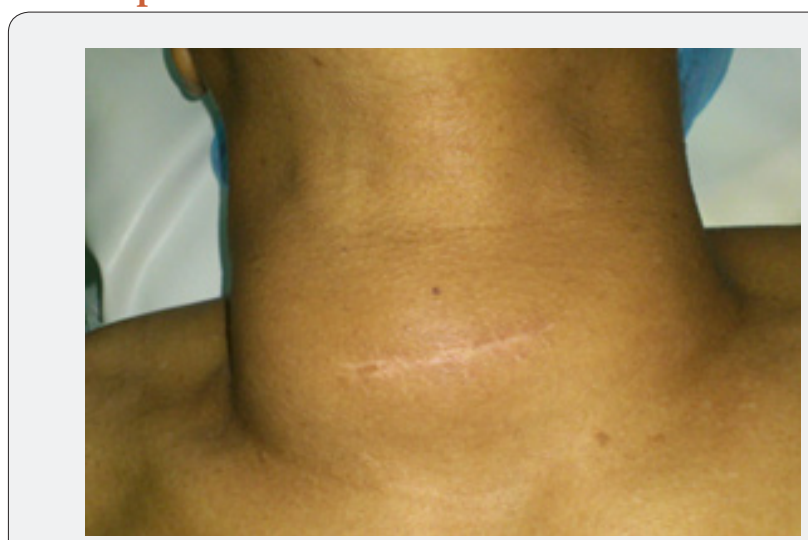

Figure 1: Hard Nodular Enlargement of Thyroid, with Biopsy Scar.

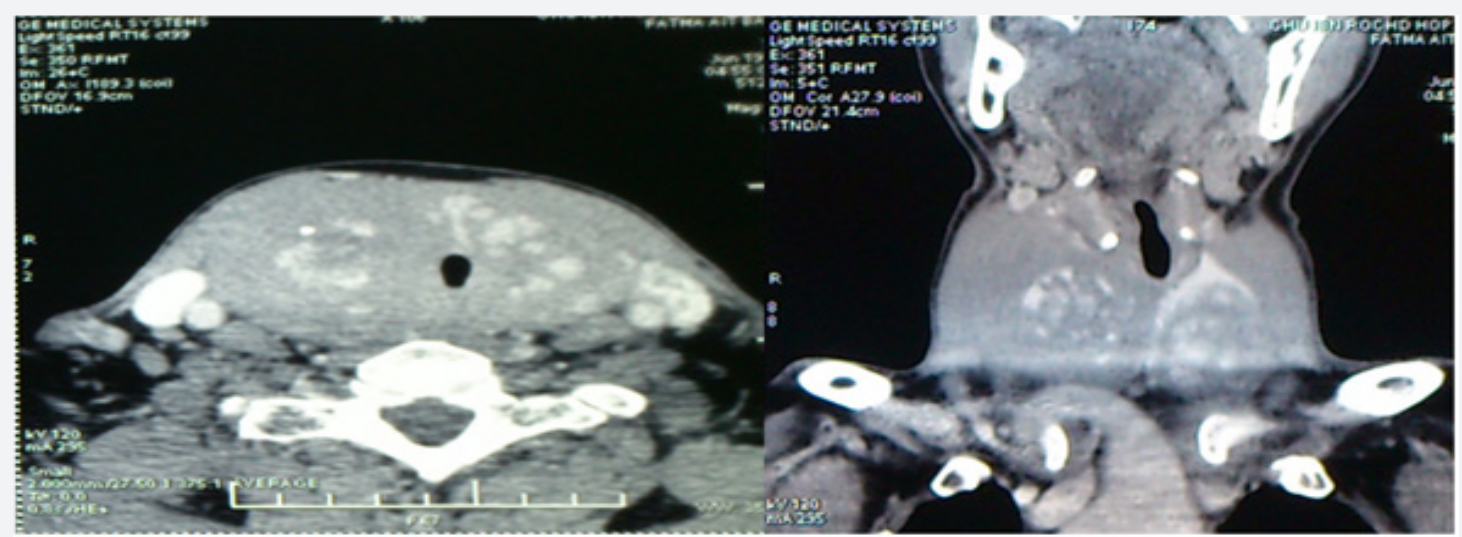

Figure 2: Heterodense mass with internal dense calcifications in CT scan, axial (A) and coronal (B) cuts. 


\section{Global Journal of Otolaryngology}

A 58-year-old women, was referred to our department with 8-month history of progressive painless anterior neck swelling without Any toxic or compressive symptom. There was no history of radiation exposure and no family history of thyroid cancer or disease. Physical examination revealed an enlarged hard and a mobile thyroid without any palpable cervical lymph nodes (Figure 1). Thyroid function test revealed a normal thyroid stimulating hormone (TSH) level of $2.87 \mathrm{IU} / \mathrm{mL}$ (reference: 0.27-4.2), CT scan showed an increased thyroid size, seat of multiple heterodenses and calcified nodules, with a left tracheal deviation with reduced diameter (Figure 2). A thyroid biopsy was performed, showed a thyroid parenchyma seat of fibro-inflammatory remodeling without evidence of specificity or malignancy. in front of the bulky aspect and tracheal deviation the patient underwent a subtotal thyroidectomy, respecting the thyroid tissue on the posterior walls to avoid parathyroid or recurrent lesions. Macroscopic examination of specimen showed a thin capsule covered the mass, and its cut surface showed mixed strips of white and yellowish-brown colors (Figure 3). Histology of specimen confirmed the Riedel thyroiditis with thyroid tissues composed of follicles of different shapes and sizes. Many of the follicles were filled with colloid. Patient was placed on oral prednisolone $40 \mathrm{mg}$ daily, and she remained free of symptoms after a one year follow up.

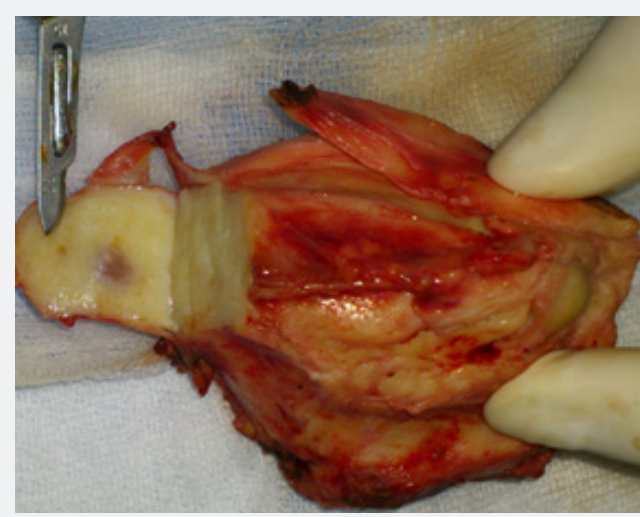

Figure 3: Macroscopic examination of specimen

\section{Discussion}

RT is a form of chronic thyroiditis, characterized by an inflammatory proliferative fibrosing process, that partially destroys the thyroid gland and extends beyond the capsule into surrounding tissues, it may be associated with idiopathic fibrosis in other sites of the body, such as the retro peritoneum [4]. Riedel thyroiditis is a very rare disease entity, and few cases have been reported in the literature, Women are mostly affected with a female to male ratio of $4: 1$ and peak age incidence is the fifth decade [2,5]. RT has no pathognomonic clinical feature. Patients usually are referred for examination of a goiter of remarkably hard consistency. The affection is of slow and progressive constitution. Initially, the consistency very firm, woody or stony goiter can simulate cancer (anaplastic cancer, thyroid lymphoma). Gradually, the gland attaches itself to the tissues adjacent (carotids, trachea, muscles, nerves) causing the compressive signs: dyspnea, dysphonia [4,6]. Initially, thyroid function is most often normal. Sometimes a hypothyroidism is observed because of the diffuse fibrosis infiltration of the gland [6]. Imaging is not specific, Ultrasound cannot distinguish RT from the other forms of thyroiditis; in fact, hypo echogenicity is a common feature in all inflammatory disorders of the thyroid gland, it is interesting that the complete absence of vascular flow at Color-Power-Doppler imaging might be demonstrated on the areas histologically diagnosed as RT, whereas most malignant nodules show intense vascularization [4]

Computed tomography reveals a hypodense, infiltrative mass, Invasion of nearby soft tissues or compression of the trachea or esophagus or a combination of these 3 characteristics might be observed. All studies that have described magnetic resonance imaging (MRI) features of RT report a homogeneous hypo intensity on both T1- and T2-weighted images [7,8]. FNA is often interpreted as non-diagnostic in cases of Riedel thyroiditis because only scant fibrous material is obtained, and definitive diagnosis requires surgical biopsy demonstrating extrathyroidal extension of the fibroinflammatory process. But it can especially exclude the neoplasia primarily [1]. There is no consensus of opinion when it comes to treatment of Riedel's thyroiditis, high dose glucocorticoids particularly prednisolone has been found to produce a good response when given as a mono drug or in combination therapy with levothyroxine. In patients who do not respond to steroid or experience recurrence on withdrawal of steroids, use of tamoxifen as sole agent or combined with steroid has been documented to improve therapy response. the best regimen and duration of therapy should be based on response and tolerability $[9,10]$. in our case the Patient was placed on oral prednisolone $40 \mathrm{mg}$ daily. The aim of surgery in patients with RT is to relieve obstructive symptoms, not to cure the disease. There is general agreement in the literature about the need of limiting the extent of operation if no malignant neoplasm is found, reducing the risk of injury to perithyroidal structures. Careful follow-up to identify and treat recurrence is advocated [4]. Our patient had to undergo surgery because preoperatively, the diagnosis of Riedel's thyroiditis was not made.

\section{References}

1. Anna-Sophie Weidner (2015) Riedel Thyroiditis: Fine Needle Aspiration Findings of a Rare Entity Diagn Cytopathol 43(9): 747-750.

2. OA Arowolo, FS Ige, O Odujoko, EA Agbakwuru (2016) Riedel's thyroiditis in a black African: A case report and review of literature. Nigerian Journal of Clinical Practice 19(4).

3. Riedel BM (1897) Vorstellung eines kranken mit chronischer strumitis. Verh Dtsch Ges Chir 26: 127-129.

4. Giampaolo Papi, Virginia A, Li Volsi (2004) Current Concepts on Riedel Thyroiditis. Am J Clin Pathol 121(Suppl 1): S50-S63.

5. Fatourechi MM, Hay ID, McIver B, Sebo TJ, Fatourechi V (2011) Invasive fibrous thyroiditis (Riedel thyroiditis): The Mayo Clinic experience, 1976-2008. Thyroid 21(7): 765-772.

6. P Perimenis, S Marcelli, E Leteurtre, M-C Vantyghem, JL Wémeau. Thyroïdite de Riedel: aspects actuels. 
7. Malotte MJ, Chonkich GD, Zuppan CW (1991) Riedel's thyroiditis. Arch Otolaryngol Head Neck Surg 117(2): 214-217.

8. Lo JC, Loh KC, Rubin AL (1998) Riedel's thyroiditis presenting with hypothyroidism and hypoparathyroidism: dramatic response to glucocorticoid and thyroxine therapy. Clin Endocrinol (Oxf) 48(6): 815-818.
9. Eryaman E, Comunoglu C (2011) Could Riedel's thyroiditis be subacute thyroiditis? A case reports. Pol J Pathol 62(3): 176-178.

10. Kosari F, Tabriz HM Saniee S (2009) Diagnostic fine needle aspiration in a case of Riedel's thyroiditis. Iran J Pathol 4(4): 186-189.

\section{Your next submission with Juniper Publishers} will reach you the below assets

- Quality Editorial service

- Swift Peer Review

- Reprints availability

- E-prints Service

- Manuscript Podcast for convenient understanding

- Global attainment for your research

- Manuscript accessibility in different formats ( Pdf, E-pub, Full Text, Audio)

- Unceasing customer service

Track the below URL for one-step submission https://juniperpublishers.com/online-submission.php 